\section{Commonwealth of Independent States (CIS)}

The Commonwealth of Independent States, founded on 8 Dec. 1991 in Belarus, is a community of independent states that proclaimed itself the successor to the Union of Soviet Socialist Republics (USSR) in some aspects of international law and affairs. When negotiations on its founding began in 1990, it sought to embrace all the 15 constituent republics of the USSR at that date. The founding members-Russia, Belarus and Ukrainewere subsequently joined by Armenia, Azerbaijan, Georgia, Kazakhstan, Kyrgyzstan, Moldova, Tajikistan, Turkmenistan and Uzbekistan. However, Turkmenistan withdrew as a permanent member in 2005 to become an associate member and Georgia withdrew altogether in 2009.

Member states are committed to recognizing the independence and sovereignty of other members, to respecting human rights including those of national minorities and to observing existing boundaries. Members agreed that Russia should take up the seat at the United Nations formerly occupied by the USSR. In March 1994 the CIS was accorded observer status at the UN. Ukraine's continued involvement with the CIS (as a participating state rather than as a full member) was thrown into doubt after Russia's annexation of Crimea in March 2014, with some politicians calling for a complete withdrawal. In Aug. 2016 Ukraine protested to the CIS over its plans to send monitors to Russian State Duma elections in Crimea.

The principal organs of the CIS, according to the agreement concluded in Alma-Ata on 21 Dec. 1991, are the Council of Heads of States and the Council of Heads of Government. There is also a Council of Defence Ministers, established in Feb. 1992, and a Council of Foreign Ministers (Dec. 1993). The Secretariat is the standing working organ.

Headquarters: 220030 Minsk, Kirova 17, Belarus.

Website (Russian only): http://www.cis.minsk.by

Email: info@e-cis.info

Executive Secretary: Sergei Lebedev (Russia).

\section{Eurasian Economic Union (EEU)}

The EEU came into being on 1 Jan. 2015 as the successor organization to the Eurasian Economic Community (EurAsEC, founded in 2000). It was established by treaty in May 2014 and provides for the free movement of goods, services, capital and labour across member states.

Membership. As of Feb. 2017 there were five member states: Armenia, Belarus, Kazakhstan, Kyrgyzstan and Russia.

Organization. The Supreme Council is the highest authority, consisting of the heads of state of the members. There is also an Intergovernmental Council, made up of the heads of government. The Eurasian Economic Commission serves as the permanent regulatory body, charged with supporting the operation and development of the Union and drafting proposals for economic integration. The Court of the EEU seeks to ensure the uniform application of all relevant treaties.

Eurasian Economic Commission Headquarters: 2 Letnikovskaya St., Bldg 1/2, Moscow 115114, Russia.

Website: http://www.eaeunion.org

Email: info@eecommission.org

Chairman of the Board of the Eurasian Economic Commission:

Tigran Sargsyan (Armenia).

\section{International Air Transport Association (IATA)}

Founded in 1945 for inter-airline co-operation in promoting safe, reliable, secure and economical air services, IATA has approximately 270 members from 112 nations worldwide. IATA is the successor to the International Air Traffic Association, founded in The Hague in 1919, the year of the world's first international scheduled services.

Main offices: IATA Centre, Route de l'Aéroport 33, PO Box 416, CH-1215 Geneva, Switzerland. 800 Place Victoria, PO Box 113,

Montreal, Quebec, Canada H4Z 1M1. 111 Somerset Road,

\#14-05 Somerset Wing, Singapore 238164.

Website: http://www.iata.org

Director-General: Alexandre de Juniac (France).

\section{International Committee of the Red Cross (ICRC)}

The International Committee of the Red Cross (ICRC) is a Swissbased impartial, neutral and independent organization ensuring humanitarian protection and assistance for victims of war and other situations of violence.

Established in 1863, the ICRC is a founding member of the International Red Cross and Red Crescent Movement and of international humanitarian law, notably the Geneva Conventions.

The ICRC is mandated by the international community to be the guardian and promoter of international humanitarian law. It has a permanent mandate under international law to take impartial action for prisoners, the wounded and sick, and civilians affected by conflict.

The ICRC aims to ensure that civilians not taking part in hostilities are spared and protected; to visit prisoners of war and security detainees and ensure that they are treated humanely and according to recognized international standards that forbid torture and other forms of abuse; to transmit messages to and reunite family members separated by armed conflict; to help find missing persons; to offer or facilitate access to basic health care facilities; to provide food, safe drinking water, sanitation and shelter in emergencies; to promote respect for, monitor compliance with and contribute to the development of international humanitarian law; to help reduce the impact of mines and explosive remnants of war on people; and to support national Red Cross and Red Crescent Societies to prepare for and respond to armed conflict and situations of violence.

The ICRC is a global presence with offices in over 80 countries and some 14,500 staff worldwide. Its HQ is in Geneva, Switzerland.

Headquarters: 19 avenue de la Paix, CH-1202 Geneva,

Switzerland.

Website: http://www.icrc.org

President: Peter Maurer (Switzerland).

\section{Further Reading}

Forsythe, David P., The Humanitarians: The International Committee of the Red Cross. 2005

Forsythe, David P. and Rieffer-Flanagan, Barbara Ann J., The International Committee of the Red Cross: A Neutral Humanitarian Actor. 2007

Moorehead, Caroline, Dunant's Dream: War, Switzerland and the History of the Red Cross. 1998 